\title{
Secondary pneumonia in tetanus patients: a review of six selected cases (Case report)
}

\author{
Herdiman T Pohan
}

\begin{abstract}
Abstrak
Tetanus merupakan infeksi oleh C.tetani yang menjadi masalah kesehatan penting di negara-negara berkembang. Perjalanan penyakitnya biasanya lama, memerlukan waktu berminggu-minggu atau berbulan-bulan untuk perawatan hingga sembuh. Beberapa penelitian telah dilakukan untuk menentukan berbagai faktor yang berpengaruh terhadap prognosis tetanus. Faktor tersebut adalah derajat spasme, usia, sedasi dan takikardia yang berpengaruh signifikan terhadap mortalitas pasien tetanus. Bila pasien tetanus dapat melewati fase akut penyakitnya, masalah lain timbul seperti disfungsi otonom dan pneumonia nosokomial (sering disebabkan oleh organisme multiresisten) sebagai penyebab tersering kematian. Laporan kasus berikut menampilkan 6 kasus tetanus, tiga di antaranya mengalami pneumonia nosokomial, dan dua di antara tiga pasien tersebut geriatri berusia 70 dan 72 tahun meninggal saat di rumah sakit. (Med J Indones 2005; 14: 117-21)
\end{abstract}

\begin{abstract}
Tetanus, an infection by C.tetani continues to be a major health problem in the developing world. The course of the disease is typically prolonged, requiring weeks to months of supportive management to resolve. Several studies have been conducted to determine which factor/s really influenced the outcome of tetanus. Factors such as severity of spasms, age, sedation and tachycardia were found to significantly influence mortality. Patients now surviving the initial acute phase of their illness, but new problems have emerged autonomic dysfunction and hospital acquired pneumonia (often with multiresistant organisms) are now the commonest causes of death. This serial cases report presents six selected cases of tetanus, three patients acquired secondary pneumonia during treatment, among the three, two patients are elderly age 70 and 72 years old. Both of the presented patients died during treatment in the hospital. (Med J Indones 2005; 14: 117-21)
\end{abstract}

Keywords: tetanus, pneumonia complication

Tetanus is caused by a toxin secreted by Clostridium tetani, a Gram-positive, obligate anaerobic bacillus that forms a stable terminal spore. ${ }^{1,2}$ The spores are noninvasive, and inoculation usually requires a disruption of the skin barrier by a foreign body. The insult to the skin barrier typically follows a deep penetrating wound. The early onset of symptoms (ie, $<48 \mathrm{~h}$ ) typically correlates with more severe disease. In most instances, clinical symptoms occur within 7 to 14 days after inoculation, although cases also have occurred almost 9 months after the injury. ${ }^{1,2}$

Division of Tropical Medicine and Infectious Diseases, Department of Internal Medicine, Faculty of Medicine University of Indonesia/Dr. Cipto Mangunkusumo National General Hospital, Jakarta, Indonesia
Nowadays much more is known about the tetanus toxin; its deoxyribonucleic acid has been sequenced and its mechanism of action established. We are equipped with antitoxin and a vaccine to prevent the disease, yet tetanus continues to be a major public health problem throughout much of the developing world. $^{3}$

In 2000 only 18,833 cases of tetanus were reported to the World Health Organization worldwide. Seventy six countries, including many of the countries most at risk, did not supply data, and the information of those that did was often incomplete. On the basis of the WHO data, studies by Stanfield and Galazka, and data from Vietnam (the hospital admits about 300 patients with tetanus each year) it is estimated a true global incidence of 700,000 to $1,000,000$ cases per year. ${ }^{3}$ Due to tetanus, about 9,8 percent of 184 thousand birth in Indonesia faced deaths. In the eighties, tetanus 
became the leading cause of death for Indonesian neonates. Beside tetanus neonatorum, maternal tetanus also compulsive to be eliminated. ${ }^{4}$

The diagnosis of tetanus is based on clinical features. ${ }^{1}$ The clinical features of tetanus arise from the action of tetanus toxin, which blocks inhibitory input of gamma aminobutyric acid to motor neurones, resulting in unchecked motor nerve activity. Muscle tone is increased. The manifestations of tetanus can be either local or general. Generalized tetanus is the most common form, with the patient presenting with pain, headache, muscle rigidity (including trismus, risus sardonicus, and opisthotonus), generalized spasms, and autonomic instability. Trismus is often the presenting symptom. Progression of the disease may lead to laryngeal obstruction and a reduction in chest wall compliance, causing respiratory failure. Respiratory failure is the most common direct cause of death from tetanus worldwide. Manifestations of autonomic instability are diverse, including hypertension or hypotension, diaphoresis, cardiac arrhythmias, and hypermetabolism. Hypotension and tachycardia complicated the course of the disease in our patient. Increased urine and plasma catecholamine levels also reflect sympathetic overactivity. In contrast, localized tetanus is less severe, and is characterized by rigidity and pain confined to the muscles adjacent to the wound. ${ }^{2,3}$

The course of the disease is typically prolonged, requiring weeks to months of supportive management to resolve. The spasms and autonomic instability are usually most prominent in the first few weeks, peaking near the second week and then resolving. However, the muscular rigidity may persist for several months. Recognizing the clinical symptoms is essential in making the diagnosis of tetanus. ${ }^{2}$

Laboratory tests usually are beneficial in riding out other diseases rather than in confirming tetanus, Wound cultures, which are positive for $\mathrm{C}$ tetani in only $30 \%$ of documented cases, have limited value. The differential diagnosis for an adult includes strychnine poisoning, orofacial infection or trauma, rabies, and drug-induced dystonic reaction. ${ }^{2}$

Several studies have been conducted to determined which factor/s really influenced the outcome of tetanus. Fifty-three cases of tetanus, 25 females and 28 males, were treated in Çukurova University Hospital during 1994-2000 by multivariate analysis, the time to mortality caused by tetanus, and also the mortality rate, were both related significantly to age and tachycardia. ${ }^{5}$ Another study on tetanus conducted in Nigeria, records of 114 patients with tetanus aged 16 and above over a ten-year period (1992-2001). Factors such as severity of spasms, age, sedation and tachycardia were found to significantly influence mortality. ${ }^{6}$ Complications include spasm of the vocal cords and/or spasms of the respiratory muscles that cause interference with breathing. Other complications include fractures of the spine or long bones, hypertension, abnormal heartbeats, coma, generalized infection, clotting in the blood vessels of the lung, pneumonia, and death. Patients experience severe pain during each spasm. During the spasm, the upper airway can be obstructed, or the diaphragm may participate in the general muscular contraction. Sympathetic overactivity is the major cause of tetanusrelated death in the intensive care unit. ${ }^{7}$

Prognosis of tetanus also depends on the facilities available. Without mechanical ventilation, asphyxia is the commonest cause of death, resulting from laryngeal muscle spasm (and acute airway obstruction), respiratory muscle spasm, or extreme fatigue. In places fortunate enough to have facilities for ventilation these problems can be overcome by using sedation and non-depolarising neuromuscualr blocking agents. Unfortunately, with patients now surviving the initial acute phase of their illness, new problems have emerged autonomic dysfunction and hospital acquired pneumonia (often with multiresistant organisms) are now the commonest causes of death. ${ }^{3}$

\section{SERIAL CASES REPORTS}

There are six selected cases of tetanus from 1998 to 2003 in Medistra Hospital Jakarta, that will be presented in this report. Two of the patients are elderly (age 70 and 72 years old) and the other four are patients in their productive years. The patients demographics, source of infectrion, risk factors/underlying disease, clinical/laboratory assesments and the complications that prevails in the course of tetanus are further described in the Table 1, 2, and 3. 
Table 1. Patient demographics data

\begin{tabular}{|c|c|c|c|}
\hline Sex & Age (years) & $\begin{array}{l}\text { Duration of treatment (days) } \\
\text { / Outcome }\end{array}$ & Presenting signs and symptoms \\
\hline Female & 72 & Died in hospital & Trismus, periodic convulsions, stridor \\
\hline Male & 70 & Died in hospital & $\begin{array}{l}\text { Neck spasm, risus sardonicus, trismus, } \\
\text { periodic convulsions, Opistotonus }\end{array}$ \\
\hline Male & 39 & 9/Survived & $\begin{array}{l}\text { Complains of stiffness in the face, neck, } \\
\text { back and abdomen, no abnormalities in } \\
\text { physical examination }\end{array}$ \\
\hline Male & 47 & 18/Survived & Neck spasm, trismus,risus sardonicus \\
\hline Male & 29 & 10/Survived & Trismus $+2 \mathrm{~cm}$, abdominal mucles rigidity \\
\hline Male & 45 & 16/Survived & $\begin{array}{l}\text { Muscular spasms especially in } \\
\text { extremities }\end{array}$ \\
\hline
\end{tabular}

Table 2. Source of infection, risk factors/underlying disease

\begin{tabular}{ll}
\hline Source of infection & Risk Factors / Underlying disease \\
\hline Laceration in the second right toe & - \\
Laceration in finger, dental focal infection & Diabetes mellitus, hypertension \\
Dental focal infection & - \\
Penetration wound(by nail) in the sole of the foot & - \\
Wound in foot & - \\
Laceration in the fifth left toe, followed by aseptic amputation & Ashtma \\
\hline
\end{tabular}

Table 3. Clinical, laboratory and radiographic data and complications

\begin{tabular}{|c|c|}
\hline Clinical, laboratory, radiographic evaluation & Complications \\
\hline $\begin{array}{l}\text { Respiratory failure, elevated WBC count }\left(30,9 \times 10^{3} / \mathrm{uL}\right) \text {, } \\
\text { bronchoalveolar lavage : Ps aeruginosa, fungal. Blood } \\
\text { culture : negative } \\
\text { Sputum culture: Ps aeruginosa, E coli, Klebsiella } \\
\text { Elevated serum ureum and creatinine (ur } 242 ; \text { cr1,7), } \\
\text { impaired liver function test } \\
\text { (serum albumin } 3,3 \text { globulin } 3,7 \text { AST } 47 \text { ALT } 21 \text {, } \\
\text { gamma GT } 348, \text { phospatase alkaline } 154 \text { ) }\end{array}$ & $\begin{array}{l}\text { Pneumonia, Urinary tract infection, Renal } \\
\text { insufficiency, liver dysfunction, Respiratory } \\
\text { failure }\end{array}$ \\
\hline $\begin{array}{l}\text { BP151/101 mmHg,HR } 106 \times / m i n, \text { urine glucose }(+) \text {, } \\
\text { hypernatremia }(147 \mathrm{mEq}) \text {, hyperkalemia }(5,3) \text {, mild } \\
\text { elevation of WBC }\left(10,5 \times 10^{3} / \mathrm{uL}\right) \text {, Sputum culture : } \\
\text { Klebsiella pneumonia, Candida albicans. Chest X-Ray: } \\
\text { Cardiomegaly }\end{array}$ & $\begin{array}{l}\text { Pneumonia (Klebsiella and Candida) with } \\
\text { hypertension and diabetes mellitus as underlying } \\
\text { disease }\end{array}$ \\
\hline $\begin{array}{l}\text { Elevated WBC count }\left(18,9 \times 10^{3} / \mathrm{uL}\right), \text { CXR: mild basal } \\
\text { pneumonia }\end{array}$ & Mild basal pneumonia \\
\hline All in normal ranges & None \\
\hline $\begin{array}{l}\text { All in normal ranges. } \\
\text { Blood culture: negative }\end{array}$ & None \\
\hline $\begin{array}{l}\text { Elevated WBC count }\left(12,5 \times 10^{3} / \mathrm{uL}\right) \text {, CXR: no signs of } \\
\text { infection. Sputum culture: Staphylococcus hemolyticus } \\
\text { and Pseudomonas stutzeri, Blood culture:negative }\end{array}$ & Ulcer in the fifth left toe amputee \\
\hline
\end{tabular}




\section{DISCUSSION}

The first two patients with tetanus are elderly, age 72 and 70 years old. Morbidity and mortality are high among elderly patients with the disease. The casefatality rate increases with age, reaching $50 \%$ in patients above 60 years of age. Both of the presented patients died during treatment in the hospital. Elderly patients account for $75 \%$ of the tetanus deaths in the United States. ${ }^{2}$ Adults aged above 60 years are at greatest risk for tetanus and tetanus-related mortality. During 1998--2000, the average annual incidence of tetanus in persons aged above 60 years was 0.03 with a case-fatality ratio of $31 \%$, both more than twice that of adults aged less than 60 years. The increased risk for tetanus with increasing age is thought to be related to the lower prevalence of protective immunity in older age groups. Protective levels of antibodies against tetanus toxoid decline with age; by age 70 years, only $30 \%$ of the population is protected. Older persons might never have received a primary vaccination series or might not have received subsequent Tetanus toxoid boosters. ${ }^{8}$

Source of tetanus infection in the patients are easily recognized, lacerations or wounds located in the extremities, and two patients with focal infection from the teeth. This data is similar with other reports on tetanus. The source of infection is usually from a wound (about 65\%), which often is minor (eg, wood or metal splinters, thorns). Chronic skin ulcers are the source in approximately $5 \%$ of cases, and in the remainder of cases, no obvious source is identified. The US Centers for Disease Control and Prevention (CDC) statistics from 1982-84 are as follows: ${ }^{7}$ infected lacerations or puncture wounds (69\%), infected chronic wounds and abscesses (20\%), exposure via intravenous drug abuse (3\%), neonates $(1 \%)$, other or no identifiable cause $(7 \%)$.

The presenting sign in most of the patients typically presented as clinical features of tetanus, except for one patient (number 3) with complains of stiffness in the face, neck and back but no signs of muscular spasms or rigidity in those areas from physical examination. The mode of clinical signs are as trismus/lock jaw (occurred in 4 of the patients), it appears that convulsions occurred more frequently in the elderly patients while muscular spasms and rigidity highlighted the clinical pictures in younger patients. Opistotonus only occurs in patient number 2. Risus sardonicus appeared in two of the patients (number 2 and 4).
To determined the complications of tetanus in these patients other laboratories and radiological examination was performed. The results of blood gas analysis in the first patient showed that the patient had respiratory failure, commencing an assisted ventilatory and respiratory intubation. Further morbidities followed the course of illness in the first patient, pneumonia with Ps aeruginosa, E coli and Klebsiella as the infecting agents (common in hospital acquired pneumonia), urinary tract infection could be elicited by the used of cathetherization, and renal insufficiency with liver dysfunction. The complexities of the problems highly suggested of MODS (multiple organ dysfunction syndrome) that usually prevails in the course of Sepsis, this patient died possibly cause of sepsis and respiratory failure. The second patient had two underlying disease which became the risk factors for worse prognosis in the patient, they are diabetes mellitus and hypertension. Diabetes contributes to immunocompromised status in the patient, predisposing the patient for secondary infection. In the second tetanus patient, the complication is Klebsiella pneumonia coinfection with candida albicans (diagnosis was confirmed from sputum culture). The patient during treatment was still in uncontrolled hypertension, the intense pain from opistotonus could raised the tension, beside the lack of proper management. The cause of death in the patient is unknown, one of the possible cause of death is cardiac arrest cause of autonomic instability in tetanus patient. The third patient at admission presented with complains of stiffness with minor injury suggesting the diagnosis of tetanus, no physical signs of tetanus that could impair the outcome of illness. During treatment the patient had mild basal pneumonia. Patient number 4 and 5 have no complications, but the course of the disease caused longer length of stay in the hospital. Patient number 6 with leucocytosis presumed to be from the healing process of his left toe amputee, there was a history of aseptic amputation after a recent laceration in the fifth left toe. Allthough the sputum culture is positive for Staphylococcus hemolyticus and Pseudomonas stutzeri, but no clinical signs or symptoms and radiologic finding confirm the diagnosis of pneumonia. The result of the culture could very well be contaminants from taking the sputum sample.

Why pneumonia become a frequent secondary infection in tetanus patient? The proposed pathopyhisiology is ensuing muscle rigidity and poor chest movements lead to the abolition of protective reflexes such as swallowing and coughing. This predisposes patients to pulmonary infections which threaten life maximally 
towards the end of the second week, when the severity of tetanus has just passed its peak. A study in India in 1986 tries to determined phagocytic and chemotactic function of human polymorphonuclear cells during tetanus infection. Phagocytosis on the day of admission was found to be half of the control values, independent of the severity of the disease; and it continued to remain low throughout the period of hospitalisation. Decreased phagocyte function of PMN is reported by McCall et al during infection. Chemotaxis like phagocytosis, in the tetanus patients was significantly low on admission, and could be due to the effect on tetanus toxin. An increase in chemotaxis was seen on day 7 , whereas on days 3 and 5 it remained low, i.e. comparable to the basal value An increase on day 7 could be related to the developing secondary infection. This findings shows decrease in phagocytic capability of PMN in tetanus patient and decreased in chemotactic function in the early course of illness that caused the patient vulnerable to secondary infection, such as pneumonia. ${ }^{9}$

\section{CONCLUSION}

From the six selected cases, we found that secondary pneumonia is a frequent complication in tetanus patients. Secondary pneumonia threaten life maximally towards the end of the second week, when the severity of tetanus has just passed its peak. Therefore pneumonia complication in tetanus patients influence the prognosis or outcome of the treatment and prolonged duration of stay in the hospital. We suggested further studies on this issue to gain more evidence and thorough understanding towards the emergence and treatment of secondary pneumonia in tetanus patients.

\section{REFERENCES}

1. Wood MJ. Tetanus. In: Armstrong D, Cohen J, editors. Infectious diseases. Philadelphia: Churchill Livingstone; 2000. p.181-5.

2. Bunch TJ, Thalji MK, Pellikka PA, et al. Respiratory failure in tetanus : case report and review of a 25 -year experience - selected reports. Chest 2002.

3. Thwaites CL, Farrar JJ. Preventing and treating tetanus : The challenge continues in the face of neglect and lack of research. BMJ 2003;326: 117-8.

4. Silalahi L. Tetanus.Tempo 2004 Apr 5 : Sect. A .4(col 1).

5. Saltoglu N, Tasova Y, Midikli D, Burgut R, Dündar IH. Prognostic factors affecting deaths from adult tetanus.Clin Microbiology \& Inf 2004;10(3): 229

6. Arogundade FA, Bello IS, Kuteyi EA, Akinsola A. Patterns of presentation and mortality in tetanus: a 10-year retrospective review.Niger Postgrad Med J 2004; 11(1): 58-63.

7. Eleftherios M. Tetanus. eMedicine [article online] Last updated 2004 Oct 27 [cited 2004 Dec 13].Available from: URL:http://www.emedicine.com/emedicine-Tetanus Article by Eleftherios Mylonakis, MD, PhD.htm

8. Bhatt AD, Dastur FD. Relapsing tetanus (a case report). J Postgrad Med 1981;27:184-6

9. Chavan UU, Karandikar SM, Dastur FD, et al. Phagocytic and chemotactic function of human polymorphonuclear cells during tetanus infection.Postgrad Med J 1986; 32(2):70-6 